\title{
Time-dependent Seismic Performance Assessment of Corroded Reinforced Concrete Frames
}

\author{
Mohammad Ghanooni-Bagha ${ }^{1 *}$, Sajad Zarei², Hamid Reza Savoj², Mohsen Ali Shayanfar ${ }^{3}$ \\ 1 Department of civil Engineering, \\ East Tehran Branch, Islamic Azad University, \\ P.O.BOX: 18735-136, Tehran, Iran \\ 2 School of Civil Engineering, \\ Iran University of Science and Technology, \\ P.O. Box 16765-163, Narmak, Tehran, Iran, \\ ${ }_{3}$ The Centre of Excellence for Fundamental Studies in Structural Engineering, \\ Iran University of Science and Technology, \\ P.O.BOX: 16765-163; Narmak, Tehran, Iran \\ *Corresponding author, e-mail: ghanoonibagha@iauet.ac.ir
}

Received: 07 June 2018, Accepted: 08 April 2019, Published online: 13 May 2019

\begin{abstract}
In this study, effects of reinforcement corrosion such as reinforcement cross section reduction, steel yield strength and concrete compressive strength reduction on RC member capacity decrease are studied. Next, a two-dimensional reinforced concrete moment resistant frame is modeled to evaluate the effects of moderate and severe intensity corrosion on moment-curvature behavior of elements and structure seismic response under nonlinear analysis. Structure capacity curves in push-over analysis and failure curves resulted from IDA for both the structure without and with corrosion are obtained and the effects of reinforcement's corrosion on the reinforced concrete frame seismic performance are determined through comparing the results. The results revealed that in terms of amount, place and type of corrosion in the reinforced concrete frame, value of the reduction resisting moment of elements is different. Furthermore, the outcomes of nonlinear analyses showed that the capacity of structure is reduced and its seismic performance level is changed as a result of corrosion.
\end{abstract}

\section{Keywords}

RC structures, corrosion, push-over analysis, IDA analysis, seismic performance

\section{Introduction}

One of the major concerns and objectives of the design and maintenance of structures in civil engineering science is the safety of structures and the preservation of human health in the event of disaster, including earthquakes, which requires proper operation, adequate resistance and expected structural performance. Various factors can have an impact on the occurrence of damage and damage to structures and, consequently, the loss of economic assets as well as human health during the earthquake. One of these factors is the corrosion of reinforcement in RC Structures, which, in addition to the long lifetime of the structures, causes several problems, such as structural cracking and early deterioration can play a role in influencing the capacity and performance of the structure during earthquake as a serious damage factor in RC Structures [1].
Today, a significant number of RC structures are subject to corrosion for various reasons, including the use of inadequate primary materials or improper handling during construction, as well as special environmental conditions [2]. Corrosion in reinforced concrete, with a change in the mechanical properties of reinforcement and concrete, will have a devastating effect on the capacity and ductility of members of the reinforced concrete structure as well as its seismic behavior and seismic performance during earthquake [3]. As the most important of these effects, it can be mentioned that the reduction of the cross-sectional area and the yield strength of reinforcement bars, the reduction of the compressive strength and tensile strength of the concrete and the bonding between the concrete and reinforcement, the occurrence of internal 
cracks in the members, and cracks in the coverage area on the reinforcements in Effect of increasing pressure on corrosion production [4]. Therefore, considering the importance of damage to the structure due to corrosion, the study of this phenomenon and its effects on the behavior of the structure is necessary more than before.

In the past years, research on corrosion in RC Structures and its effects on nonlinear behavior and seismic performance of structures have been made. Shayanfar et al. [5], Berto et al. [6] and Ouglova et al. [7] investigate the corrosion effects of the bond between concrete and steel, Liu and Weyers [8], Li et al. [9] and Ghanooni-Bagha et al. [10] have investigated cracking and reduction of the concrete strenght due to corrosion. Also, Ghanooni-Bagha et al. [11, 12] have investigated the nonlinear behavior of short buildings and a steel structure by using Pushover analysis. In addition, Inci et al. [13], and Yalciner et al., expanded their research $[1,14]$, in addition to examining the phenomenon and mechanism of corrosion and Its effects on the properties of concrete and reinforcements, have been studied the corrosion effects on nonlinear behavior and seismic performance of RC structures. Inci et al., by modeling a moment-frame of reinforced concrete under the types of cavity corrosion of reinforcement in frame columns, calculated the corrosion effect on steel properties and evaluated the failure area for each corrosion scenario using nonlinear analysis. Yalciner et al., by modeling a single-degree-of-freedom frame, as well as studying on a 50-year-old concrete building, have been evaluating the seismic performance of structures under the influence of uniform corrosion as a function of time. For this purpose, considering the different time periods for corrosion, they have evaluated the moment-curvature properties of the cross section, and then, by conducting nonlinear analyzes, have studied the effect of corrosion on the structural seismic performance. Fema-356 recommends the use of the anchor curvature of sections without corrosion with an awareness coefficient of 0.75 in the corrosion structures [15]. However, this number is independent of the percentage of corrosion and damage caused. Therefore, in this study, it is proposed to obtain a precise anchor-curve curve considering the corrosion effects under different degrees of corrosion as a more appropriate and more accurate alternative for the coefficient of consciousness.

According to the articles, in this research, by presenting and developing two models of concrete moment-frame with multi-degree-of-freedom, the effect of different kinds of corrosion (pitting and uniform) with low and high intensity on the capacity and performance of the frame has been studied. Corrosion effects on the properties of materials, including compressive strength of concrete, the yield strength and modulus of elasticity of steel and reinforced cross-sections, have been calculated using different models. Finally, by analyzing nonlinear static analysis (Pushover) and incremental dynamic analysis (IDA), the effects of this phenomenon on the overall nonlinear behavior of the entire structure, in particular, have been evaluated as having an impact on its capacity and seismic performance level during the earthquake as a function of time to estimate the degree of corrosion effects in different states and intensities.

\section{Corrosion effects on the properties of concrete and steel 2.1 Changes in the mechanical properties of the steel and the cross section of the reinforcement bars}

In order to evaluate the effect of corrosion on mechanical properties of steel, Han-Seung Lee and Young-Sang Cho have conducted a series of experiments on a variety of laboratory samples to provide a model for defining the relationship between corrosion and mechanical properties of steel, yield strength and modulus of elasticity. The model presented by Lee and Cho was developed to evaluate and calculate the decrease in the yield strength and the modulus of elasticity of steel based on the corrosion percentage in both types of uniform and pitting corrosion [16]. In addition to changing the properties of steel due to corrosion, the cross-sectional reinforcement also decreases. Different relationships and models are presented to estimate the amount of this decline. One of the models is the model provided by Rodriguez et al. Which is used in the uniform type corrosion. This model calculates the amount of reduction in the diameter of the reinforcement based on the time elapsed since the beginning of the corrosion process and the corrosion rate of the reinforcement [17]. But in the case of pitting corrosion based on the model provided by Val and Melchers, the maximum corrosion penetration into the reinforcement is between 4 to 8 times the average of corrosion penetration in uniform type of corrosion. Based on this model, the radius of the pit is calculated, and then the amount of residual area of the cross-section of the reinforcement after the penetration of corrosion is obtained [18].

\subsection{Reduced compressive strength of concrete}

Another consequence of the occurrence of corrosion in concrete is a significant increase in the volume of reinforcement due to the production of corrosion products, which causes a radial compression force across the reinforcement 
surface and, as a result, creates tensile stresses in the concrete around the reinforcement. This causes concrete to crack and reduce the compressive strength of the concrete. It should be noted that this process, in a uniform type of corrosion, is more likely than corrosion of a pitting type. For modeling this process and its effect on the compressive strength of concrete, equation have been used by Shayanfar and Ghanoonibagha model [10, 19].

\section{Material behavior modeling}

\subsection{Stress-strain model of concrete}

In order to model material behavior, Kent and Park have provided relationships for modeling stress-strain behavior of concrete in the structure. Scott corrected these relationships [20], according to which the behavior of the concrete in pressure, with three stratigraphic regions before the strain is equal to the maximum compressive stress, the strain can be defined before the strain equivalent to the rupture and strain after the strain equivalent to the rupture . On the other hand, based on this model, the behavior of concrete in tension is linear elastic, which, after reaching the tensile stress of the section, to the tensile strength of the concrete, with the increase of the strain in the concrete, the tensile stress is linearly reduced to the extent that the tensile strain of the concrete It reaches $\varepsilon_{0}$, which is in fact a strain like tensile failure in concrete. This amount of tensile strain, originated from micro-cracks that, by increasing and joining together, has led to the creation of larger cracks in concrete and the so-called strain smoothing [21].

\subsection{Stress-strain model of steel}

The behavior of steel used in reinforcement bars is defined simply by a bilinear diagram including a linear elastic part and an elastic part related to strain hardening after the point of yielding. The reason for this simplification is, in addition to simplifying the types of calculations, that in the members of the RC sections, the behavior of these members is affected by the bending moments, greatly affected by the yielding of the reinforcement bars, and the conditions and resistance after yielding, have no significant effect on the evaluation results and analysis [21].

\section{Case study}

As discussed earlier, the main objective of this study is to evaluate the levels of seismic performance of RC frames exposed to corrosion. Therefore, two two-dimensional and three-dimensional models of moment-frame are considered for this purpose.

\subsection{Two-dimentional frame model}

The first model is a two-dimensional RC frame with four floors and three spans (Fig. 1 and Table 1-2). Model specifications are based on Haselton et al. benchmark [22]. In this reference, Haselton et al., have evaluated the seismic safety and failure of $30 \mathrm{RC}$ frames using nonlinear analyzes. With the development of one of these models and considering the effects of corrosion, the results of this analysis are presented in this study.

The building has office occupancies. The roof system is a flat slab with a thickness of $20 \mathrm{~cm}$ and a plan of 36.6 meters in 54.98 meters. The strength of the concrete is 350 $\mathrm{kg} / \mathrm{cm}^{2}$ and the concrete strength of the first floor columns is $490 \mathrm{~kg} / \mathrm{cm}^{2}$. Also, the amount of yield strength of reinforcement bars is $4220 \mathrm{~kg} / \mathrm{cm}^{2}$. The amount of gravity load on the beams of the floors is uniform and equal to 2880 $\mathrm{kg} / \mathrm{m}$. Also, the value of the modulus of elasticity of the concrete is calculated using the ACI318-08 and the modulus of elasticity of steel, calculated using the AISC36010. two dimensional model of the moment-frame is modeled using Opensees software [23]. The modeling of the elements includes the plasticity beam-column elements and the finite joint shear panel springs. In modeling of beam-column elements, non-linear hinge model provided by Ibarra et al., [24] have been used.

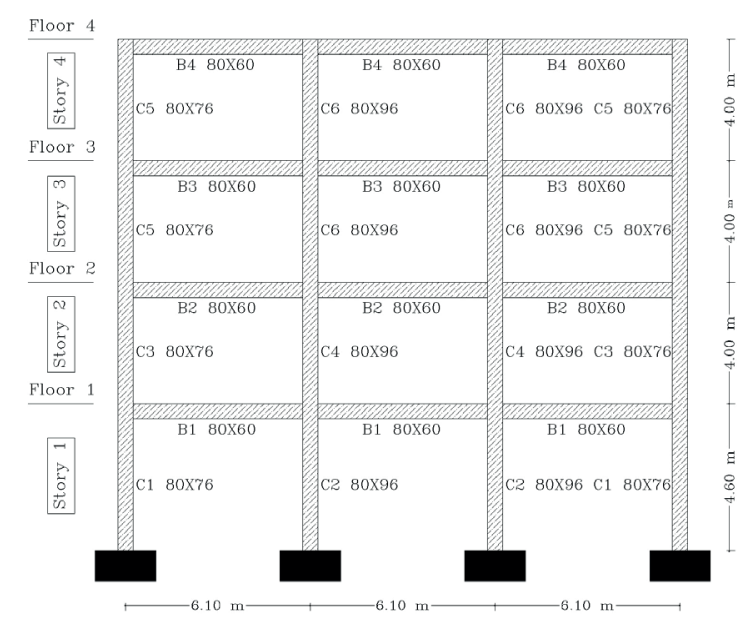

Fig. 1 Characteristics of the two-dimentional RC frame

Table 1 Characteristics of the columns of the two-dimentional RC frame

\begin{tabular}{lccc}
\hline Column & $\rho_{\text {tot }}$ & $\rho_{\text {sh }}$ & $\mathrm{S}_{\mathrm{cm}}$ \\
\hline $\mathrm{C} 1$ & 0.021 & 0.0085 & 8.9 \\
$\mathrm{C} 2$ & 0.016 & 0.0112 & 8.9 \\
$\mathrm{C} 3$ & 0.010 & 0.0085 & 8.9 \\
$\mathrm{C} 4$ & 0.0112 & 8.9 \\
$\mathrm{C} 5$ & 0.010 & 0.0061 & 10.2 \\
C6 & 0.010 & 0.0080 & 8.9 \\
\hline
\end{tabular}


Table 2 Characteristics of the beams of the two-dimentional RC frame

\begin{tabular}{lcccc}
\hline Beam & $\rho$ & $\rho^{\prime}$ & $\rho_{\text {sh }}$ & $\mathrm{S}_{\mathrm{cm}}$ \\
\hline B1 & 0.0108 & 0.0123 & 0.0051 & 12.7 \\
B2 & 0.0100 & 0.0115 & 0.0048 & 12.7 \\
B3 & 0.0093 & 0.0108 & 0.0039 & 12.7 \\
B4 & 0.0048 & 0.0060 & 0.0029 & 12.7 \\
\hline
\end{tabular}

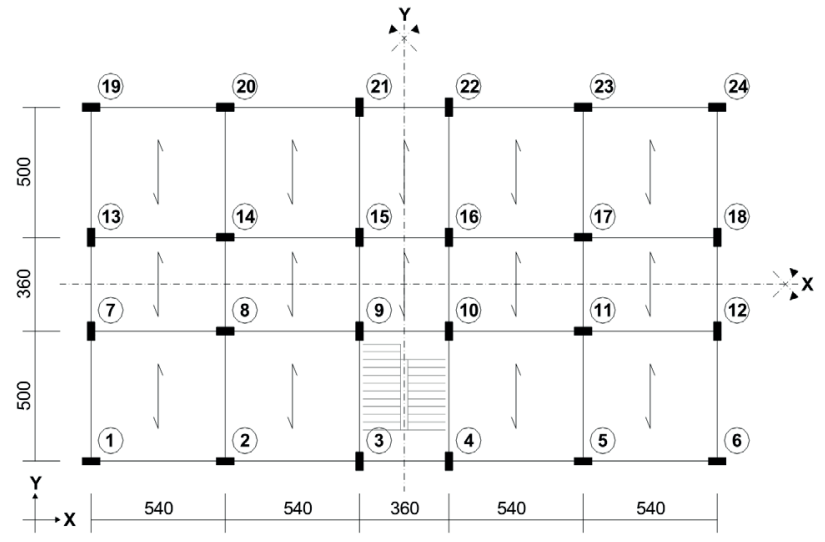

Fig. 2 Characteristics of the three-dimentionalstructure [25]

\subsection{D Structure model}

The 3D model is a four-story concrete structure, regular in plan and height, selected on the basis of reference number [25]. The dead and live load on the floors is equal to $600 \mathrm{~kg} / \mathrm{m}^{2}$ and $200 \mathrm{~kg} / \mathrm{m}^{2}$ respectively. The average compressive strength of the concrete with a cylindrical sample is $335 \mathrm{~kg} / \mathrm{cm}^{2}$ and the reinforcement yield strength is $5000 \mathrm{~kg} / \mathrm{cm}^{2}$. The plan details and sections used in the structure are presented in Fig. 2, and Table 3-4. The effective period of the structure in the direction of $x$ is 0.59 and in the direction $y$ is 0.83 seconds. $\delta_{x}=12 \mathrm{~cm}, \delta_{y}=18.7 \mathrm{~cm}$ target point displacement is obtained, which is based on Fema-356, the value of $1.5 \delta_{x}=18 \mathrm{~cm}, 1.5 \delta_{y}=28 \mathrm{~cm}$ are considered for drawing diagrams into the software.

\section{Moment-curvature analysis}

\subsection{Two-dimentional frame model}

In this model it is assumed that due to the penetration of chloride ion into the concrete in B1 beam on the first floor, the kind of pitting corrosion is happens. Also, carbon dioxide penetration into the concrete on the fourth floor leads to a uniform corrosion in B4 beam. The effect of corrosion on the cross-sectional area of the reinforcements, the yield strength and the elasticity modulus of the steel, as well as the compressive strength of the concrete, are based on the models presented. The moment-curvature analysis was carried out in corrosion at low intensity of 1.8 and $6.3 \%$, respectively, in B1 and B4 and 24.6\% and $24.0 \%$, in B1 and B4, respectively. In addition, once, corrosion effects are considered on all cases and again, the analysis is done without considering the effect of corrosion on the yield strength and modulus of elasticity of the steel. It should be noted that in high intensity corrosion it can be assumed that some concrete in the radius of cover on the reinforcement and in the center of the reinforcement is affected by corrosion and the concrete of the cover area due to large cracking has been lost.

\subsection{Three-dimentional structure model}

In the three-dimensional structure, the structure was analyzed in the following states with the consideration of high and low intensity of uniform corrosion in beams and columns, and the effect of corrosion on the cross section area of the reinforcement, the compressive strength of the concrete and the final deformation of the reinforcement.

1. Structure without corrosion effect using moment-curvature curve in Matlab code.

2. Structure without corrosion effect using moment-curvature curve proposed by Fema-356.

3. Structure with low intensity corrosion effect of $8.6 \%$ based on reference suggestions [25].

4. Structure with high intensity corrosion effect $25 \%$ reduced cross-sectional reinforcement.

5. Structure with corrosion with a knowledge factor of 0.75 based on Fema-356.

Table 4 Characteristics of the column sections in the three-dimentional structure [25]

\begin{tabular}{lcc}
\hline & Column n. & Column n. \\
\hline & $1,2,5,6,19,20,23,24$ & $3,4,7-18,21,22$ \\
along the $60 \mathrm{~cm}$ side & $8+8 \varphi 16$ & $9+9 \varphi 16$ \\
along the $30 \mathrm{~cm}$ side & $6+6 \varphi 16$ & $8+8 \varphi 16$ \\
stirrups & \multicolumn{2}{c}{$\varphi 8 / 20 \mathrm{~cm}$} \\
\hline
\end{tabular}

Table 3 Characteristics of the beam sections in the three-dimentional structure [25]

\begin{tabular}{|c|c|c|c|c|c|c|c|c|c|c|}
\hline & \multicolumn{2}{|c|}{ Beam 1-2 } & \multicolumn{2}{|c|}{ Beam 2-3 } & \multicolumn{2}{|c|}{ Beam 3-4 } & \multicolumn{2}{|c|}{ Beam 1-7 } & \multicolumn{2}{|c|}{ Beam 7-13 } \\
\hline & 1 & 2 & 2 & 3 & 3 & 4 & 1 & 7 & 7 & 13 \\
\hline top & $8 \varphi 16$ & $8 \varphi 16$ & $8 \varphi 16$ & $5 \varphi 16$ & $5 \varphi 16$ & $5 \varphi 16$ & $6 \varphi 16$ & $9 \varphi 16$ & $9 \varphi 16$ & $9 \varphi 16$ \\
\hline bottom & $6 \varphi 16$ & $5 \varphi 16$ & $5 \varphi 16$ & $3 \varphi 16$ & $3 \varphi 16$ & $3 \varphi 16$ & $5 \varphi 16$ & $9 \varphi 16$ & $9 \varphi 16$ & $9 \varphi 16$ \\
\hline stirrups & \multicolumn{10}{|c|}{$\varphi 8 / 10 \mathrm{~cm}$} \\
\hline
\end{tabular}




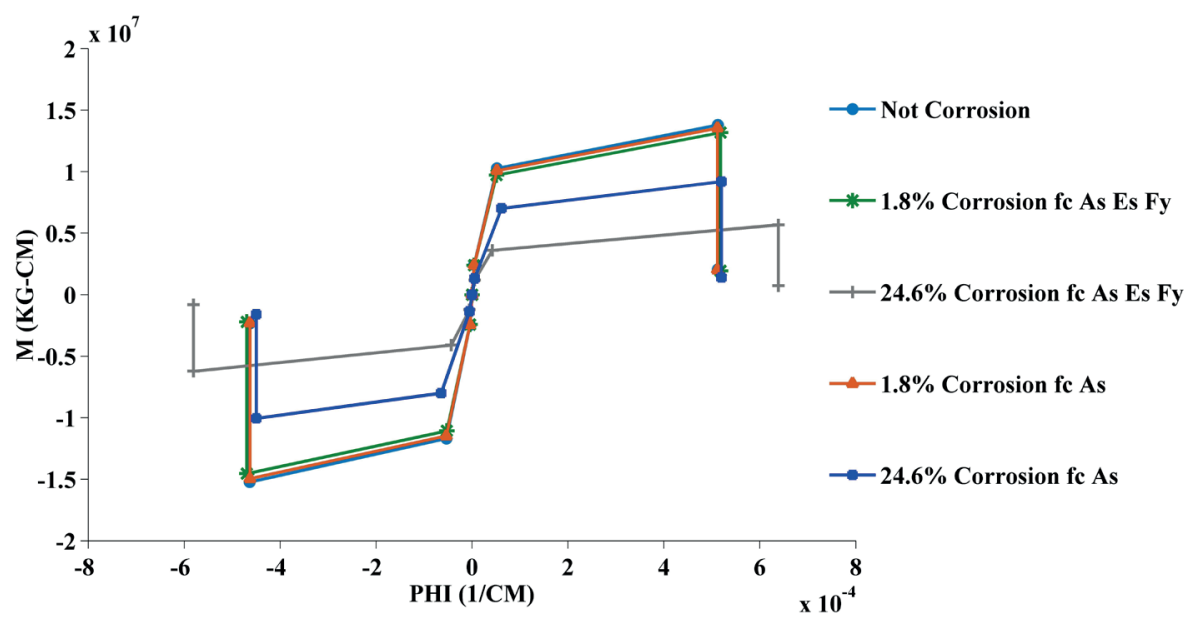

Fig. 3 Moment-curvature curve of B1 in two-dimentional frame

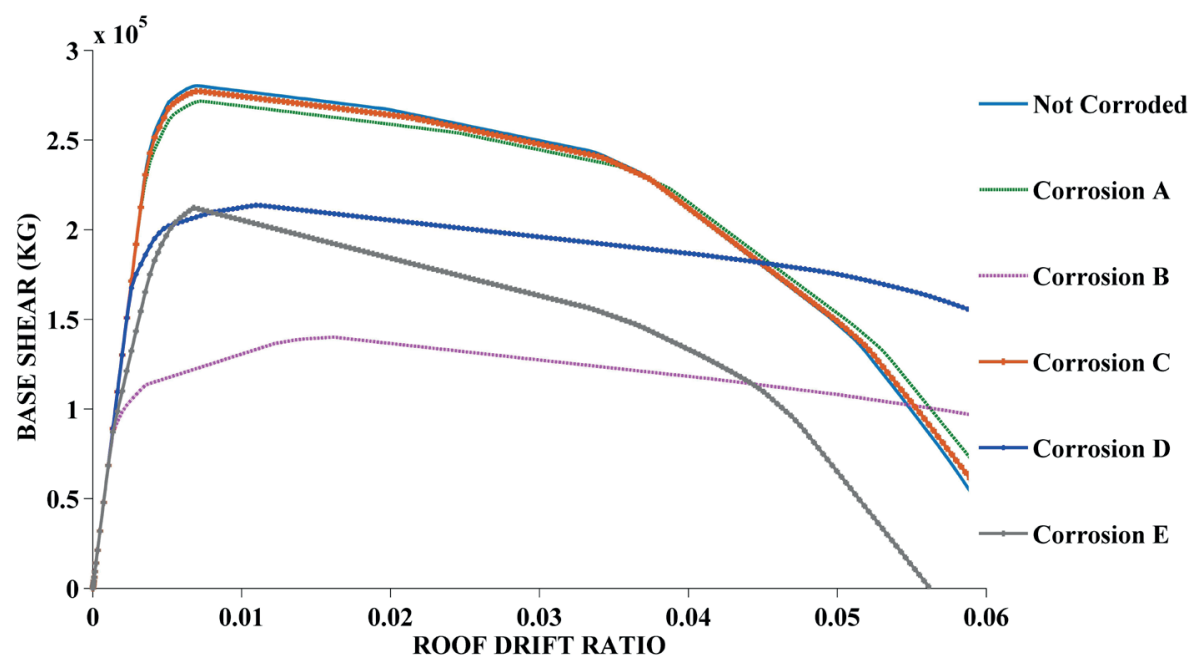

Fig. 4 Pushover analysis results for the two-dimentional frame

The results of the B1 beam analysis of a two-dimensional frame model are shown in Fig. 3.

The results of the analysis show that in low intensity corrosion, the $M_{u}$ and the $P h i_{u}$ (ultimate moment and curvature) of the section are slightly reduced, but in high intensity corrosion, the $M_{u}$ and the $P h i_{u}$ shows a significant decrease and increase respectively. According to the results of the moment-curvature analysis, for the nonlinear analysis of the seismic behavior of the structure under corrosion, for each of the studied models, five corrosion states are considered. In the three-dimensional structure, the states presented in Section 5.2 and in the two-dimensional frame are as follows:

A) Uniform and pitting corrosion with low intensity with taking all factors into consideration in the beams (B4) and (B1, B2, B3) respectively,

B) Uniform and pitting corrosion with high intensity with taking all factors into consideration in the beams (B4) and (B1, B2, B3) respectively,
C) Uniform and pitting corrosion with low intensity without considering the effect on $f y$ and $E s$, in beams (B4) and (B1, B2, B3) respectively,

D) Uniform and pitting corrosion with high intensity without considering the effect on $f y$ and $E s$, in beams (B4) and (B1, B2, B3) respectively,

E) Uniform and pitting corrosion with high intensity in beams (B4) and (B1) and with low intensity in beams (B2, B3), taking into account all factors.

\section{Pushover analysis}

Nonlinear static analysis (Pushover) is performed to evaluate nonlinear behavior and calculate structural capacity. The base shear values are plotted against the relative displacements in the control point, which is actually the roof center of mass. Pushover analysis results for the two-dimensional frame is presented in Fig. 4 and Table 5. 
Table 5 Pushover analysis results for the two-dimentional frame

\begin{tabular}{|c|c|c|c|c|c|c|}
\hline Structure condition & Not Corroded & Corrosion (A) & Corrosion (B) & Corrosion $(\mathrm{C})$ & Corrosion (D) & Corrosion (E) \\
\hline Base shear (kg) & 280357 & 271742 & 140050 & 277262 & 213643 & 212225 \\
\hline $\begin{array}{l}\text { Change to non-corroded } \\
\text { condition }\end{array}$ & ----- & $3.07 \%$ decrease & $50.05 \%$ decrease & $1.10 \%$ decrease & $23.80 \%$ decrease & $24.30 \%$ decrease \\
\hline
\end{tabular}

Table 6 Comparison of the base shear and nonlinear hinges at the displacement $\delta \mathrm{t}$ in the 3D model

\begin{tabular}{|c|c|c|c|c|c|c|c|c|c|c|}
\hline Condition & Base shear $(\mathrm{kg})$ & A to $B$ & $\mathrm{~B}$ to $\mathrm{IO}$ & IO to $\mathrm{LS}$ & $\mathrm{LS}$ to $\mathrm{CP}$ & $\mathrm{CP}$ to $\mathrm{C}$ & $\mathrm{C}$ to $\mathrm{D}$ & $\mathrm{D}$ to $\mathrm{E}$ & Beyond $\mathrm{E}$ & Total \\
\hline $0 \%$ MATLAB & 893011 & 374 & 94 & 24 & 0 & 0 & 4 & 0 & 0 & 496 \\
\hline $8.6 \%$ MATLAB & 834474 & 368 & 94 & 26 & 0 & 0 & 8 & 0 & 0 & 496 \\
\hline $25 \%$ MATLAB & 614021 & 366 & 66 & 38 & 0 & 0 & 26 & 0 & 0 & 496 \\
\hline $0 \%$ Fema-356 & 819130 & 374 & 92 & 30 & 0 & 0 & 0 & 0 & 0 & 496 \\
\hline $\begin{array}{l}\text { Fema-356 with } \mathrm{k}=0.75 \\
\text { in capacity limit }\end{array}$ & 664052 & 352 & 74 & 60 & 0 & 0 & 10 & 0 & 0 & 496 \\
\hline $\begin{array}{l}\text { Fema-356 with } \mathrm{k}=0.75 \\
\text { in deformation limit }\end{array}$ & 827241 & 374 & 72 & 48 & 0 & 0 & 2 & 0 & 0 & 496 \\
\hline
\end{tabular}

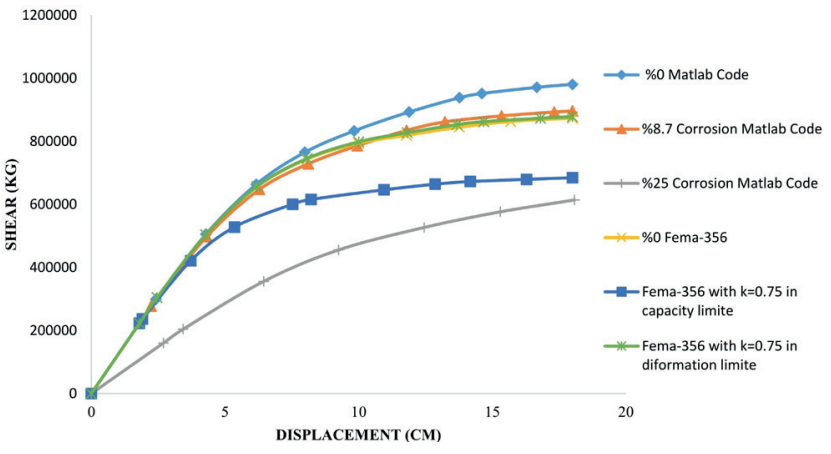

Fig. 5 Pushover analysis results for the 3D model-capacity curve in $\mathrm{x}$ direction

By comparing the results, it can be seen that with the occurrence of corrosion, the maximum base shear is lower than the non-corroded condition, which is more than the amount of this reduction in the situation where the corrosion effect is taken into account for all concrete and steel specifications. This result is a good illustration of the corrosion impact on structural capacity.

In the 3D model, according to the characteristics of each member, under the different corrosion conditions, the structure was analyzed and the relationships between the base shear and the control point or the center of mass of the roof displacement in each conditions of corrosion was obtained under uniform lateral load pattern, Push_Acc_X which shown in Fig. 5. It should be noted that this curve is for the push of the structure to $1.5 \delta$ for all conditions and to $1.0 \delta$ for the $25 \%$ corrosion condition.

Comparison of the results of the MATLAB code shows that in the corrosion of $8.6 \%$, the base shear was reduced by $6.5 \%$ compared to the non-corrosion condition, and in the corrosion of $25 \%$, the base shear was reduced by $31 \%$.
As it is seen, applying the coefficient $k=0.75$ in deformation does not have much effect on the structural capacity. Also, application of the coefficient $k=0.75$ in the capacity of sections for low intensity corrosion $(8.6 \%)$ is non-economical and unsafe for high intensity corrosion (25\%) (Table 6).

\section{Incremental Dynamic Analysis (IDA)}

In order to accurately evaluate the seismic performance of the structure as a function of time, after moment-curvature and Pushover analysis, the 2D frame model with the corrosion condition (A) and (B) is included in the incremental dynamic analysis (IDA). For this purpose, by selecting 20 earthquake records near fault of the PEER with the aim of covering a sufficient range of structural responses under probable earthquakes, incremental dynamic analysis with acceleration step of 0.05 was performed and the ratio of drift of floors for different values of the acceleration in the first mode, is obtained. The result of this analysis is the failure curve (IDA) including the incremental values of spectral acceleration in the first mode of the structure versus the maximum interstory drift ratio for the twenty earthquake records, which for not corroded state and with the corrosion condition (A) and (B) are shown in Fig. 6 and Fig. 7 and Fig. 8 respectively. The characteristics of the twenty earthquake records are presented in Table 7.

Since it is not known which of the earthquake records applied to it during the useful life of the structure, in order to simplify the evaluation and generalize the results of the analysis, using probability values of $16 \%, 50 \%$ and $84 \%$, the failure curve (IDA) is summarized as a curve for twenty earthquake records. This means that the maximum interstory drift ratio corresponding to $16 \%$ and $50 \%$ 
Table 7 Characteristics of the twenty earthquake record [26]

\begin{tabular}{|c|c|c|c|c|c|c|}
\hline Number & Event & Station & Angle $\left({ }^{\circ}\right)$ & M & PGA (g) & $\mathrm{PGV}(\mathrm{cm} / \mathrm{s})$ \\
\hline 1 & Imperial Valley-06, 1979 & El Centro Array \#6 & 140 & 6.53 & 0.35 & 58.35 \\
\hline 2 & Irpinia Italy-01, 1980 & Sturno (STN) & 0 & 6.9 & 0.21 & 26.05 \\
\hline 3 & Superstition Hills-02, 1987 & Parachute Test Site & 225 & 6.54 & 0.43 & 62.90 \\
\hline 4 & Loma Prieta , 1989 & Saratoga-Aloha Ave & 0 & 6.93 & 0.31 & 26.41 \\
\hline 5 & Erzican Turkey , 1992 & Erzincan & EW & 6.69 & 0.38 & 53.98 \\
\hline 6 & Cape Mendocino , 1992 & Petrolia & 0 & 7.01 & 0.58 & 49.30 \\
\hline 7 & Landers , 1992 & Lucerne & 260 & 7.28 & 0.65 & 133.33 \\
\hline 8 & Northridge-01, 1994 & Rinaldi Receiving Sta & 228 & 6.69 & 0.68 & 147.92 \\
\hline 9 & Northridge-01, 1994 & Sylmar-Olive View Med FF & 90 & 6.69 & 0.60 & 49.36 \\
\hline 10 & Kocaeli Turkey, 1999 & Izmit & 90 & 7.51 & 0.23 & 38.27 \\
\hline 11 & Chi Chi Taiwan . 1999 & TCU065 & $\mathrm{E}$ & 7.62 & 0.79 & 125.28 \\
\hline 12 & Chi Chi Taiwan . 1999 & TCU102 & $\mathrm{E}$ & 7.62 & 0.26 & 67.03 \\
\hline 13 & Duzce Turkey , 1999 & Duzce & 180 & 7.14 & 0.28 & 180 \\
\hline 14 & Gazli USSR , 1976 & Karakyr & 0 & 6.8 & 0.59 & 66.18 \\
\hline 15 & Imperial Valley-06, 1979 & Bonds Corner & 140 & 6.53 & 0.52 & 39.76 \\
\hline 16 & Loma Prieta , 1989 & BRAN & 0 & 6.93 & 0.36 & 37.73 \\
\hline 17 & Cape Mendocino , 1992 & Cape Mendocino & 0 & 7.01 & 1.49 & 34.88 \\
\hline 18 & Northridge-01, 1994 & LA-Sepulveda VA Hospital & 270 & 6.69 & 0.52 & 77.63 \\
\hline 19 & Kocaeli Turkey, 1999 & Yarimca & 60 & 7.51 & 0.20 & 69.68 \\
\hline 20 & Denali Alaska, 2002 & TAPS Pump Station \#10 & 47 & 7.9 & 0.30 & 115.66 \\
\hline
\end{tabular}

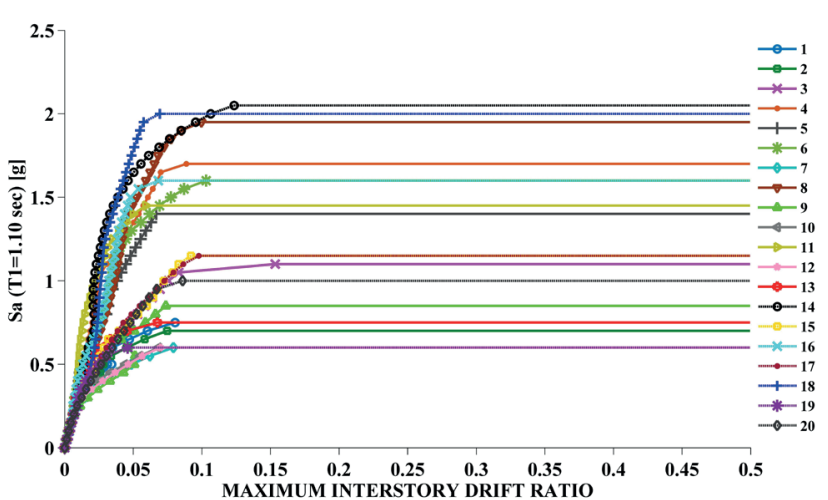

Fig. 6 Not-corroded two-dimentional frame failure curve in IDA analysis

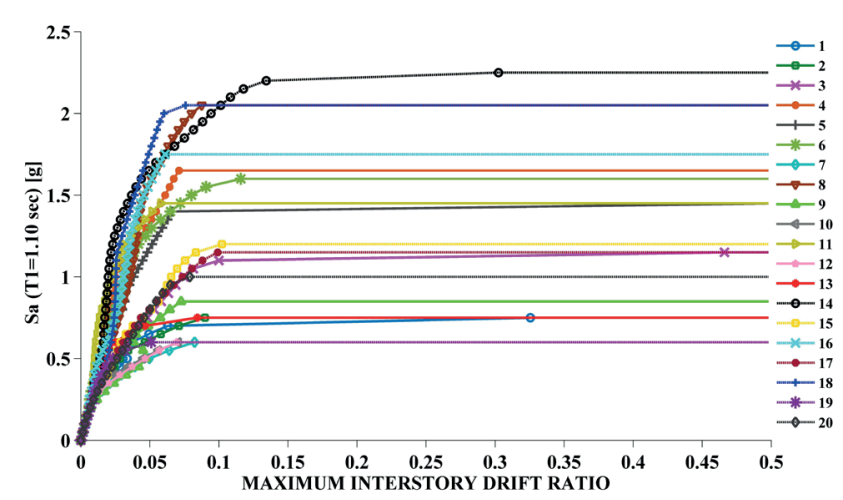

Fig. 7 Corrosion (A) two-dimentional frame failure curve in IDA analysis

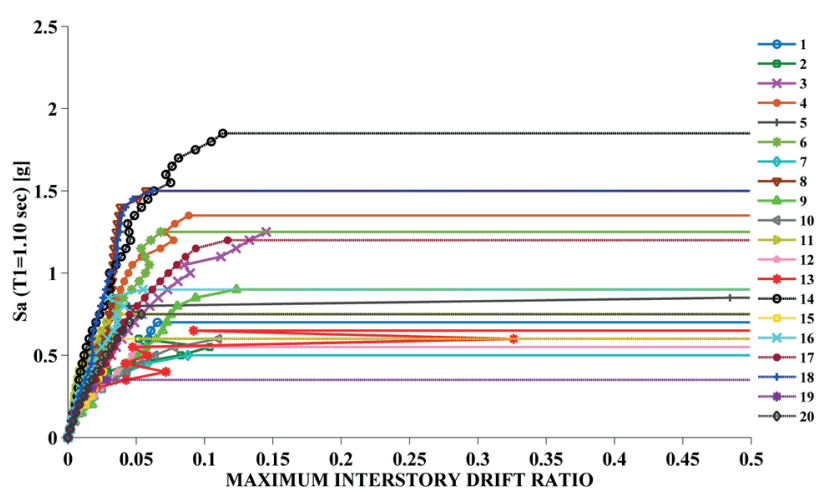

Fig. 8 Corrosion (B) two-dimentional frame failure curve in IDA analysis

and $84 \%$ of the earthquake records are plotted against the values of the spectral acceleration in the first mode of the structure. The results of this analysis for not corroded state and corrosion condition (A) and (B) are shown in Figs. 9-11, respectively.

According to the above curves, it is concluded that in $S_{a}=0.35 \mathrm{~g}$, which is equal to the acceleration of the spectrum in Tehran, $84 \%$ of earthquake records, in the sate of not-corroded, cause a maximum interstory drift ratio of more than 0.0097 in the structure. However, $50 \%$ and $16 \%$ of the earthquake records will result in a maximum interstory drift ratio of more than 0.0126 and 0.0189 , respectively. FEMA 356 [15] sets the values of the maximum drift 
Table 8 Seismic performance levels in not-corroded and with corrosion (A) and (B)

\begin{tabular}{lcccccc}
\hline Limit states & \multicolumn{2}{c}{ Not-corroded } & \multicolumn{2}{c}{ Corrosion $(\mathrm{A})$} & \multicolumn{2}{c}{ Corrosion $(\mathrm{B})$} \\
\hline & MIDR $\left(S_{a}=0.35 \mathrm{~g}\right)$ & Performance level & MIDR $\left(S_{a}=0.35 \mathrm{~g}\right)$ & Performance level & MIDR $\left(S_{a}=0.35 \mathrm{~g}\right)$ & Performance level \\
$16 \%$ & 0.0189 & LS & 0.0193 & LS & 0.0303 & CP \\
$50 \%$ & 0.0126 & LS & 0.0130 & LS & 0.0203 & CP \\
$84 \%$ & 0.0097 & IO & 0.0098 & IO & 0.0119 & LS \\
\hline
\end{tabular}

ratio corresponding to each performance level (IO) and (LS) and (CP) respectively $1 \%, 2 \%$ and $4 \%$. With respect to these values, it can be concluded that the structure in the spectral acceleration $S_{a}=0.35 \mathrm{~g}$, influenced by $84 \%$ of the earthquakes at the performance level (IO), affected by $50 \%$ of the earthquakes at the performance level (LS) and under Effect of $16 \%$ of earthquakes at performance level (LS). However, in the corrosion condition(A), which is related to low intensity corrosion in beam reinforcements, in $S_{a}=0.35 \mathrm{~g}, 84 \%$ of earthquake records produce a maximum interstory drift ratio of more than 0.0098 , as well as $50 \%$ and $16 \%$ of the earthquake records will cause the maximum drift ratio to be greater than 0.0130 and 0.0193 in the structure, respectively. Also, for corrosion condition (B) for high intensity corrosion in beams, in $S_{a}=0.35 \mathrm{~g}$, $84 \%$ of earthquake records produce a maximum drift ratio of more than $0.0119,50 \%$ and $16 \%$ of earthquake records respectively The maximum drift ratio is greater than 0.0203 and 0.0303 . It is concluded that in condition (A), the structure under $84 \%$ of the earthquakes is at the performance level (IO), subjected to $50 \%$ of the earthquakes is at the performance level (LS) and under $16 \%$ of the earthquakes is at the performance level (LS). In condition (B), the structure under $84 \%$ of the earthquakes is at the performance level (LS) and under $50 \%$ and $16 \%$ of the earthquakes is at the performance level (CP) (Table 8).

According to the above results, it can be concluded that in the $2 \mathrm{D}$ structure, with low level of corrosion in reinforcement, the level of seismic performance of structure does not change, but the amount of drifts increases slightly. In high intensity corrosion, the change in the seismic performance levels of the building is such that, under $84 \%$ of the earthquakes, the level of performance from (IO) to (LS) and under $50 \%$ and $16 \%$ of the earthquakes the performance level from (LS) to (CP) changes.

These results shows the importance of the effect of corrosion, especially high intensity corrosion, on structural behavior and performance during a seismic event. Therefore, in order to provide more safety to structures during the earthquake, the corrosion phenomenon in $\mathrm{RC}$
Structures is considered as a matter of importance and sufficient preventive studies and preventive measures are taken during the design and construction of such structures, as well as to maintenance and repair structural exposures to corrosion should be sufficient.

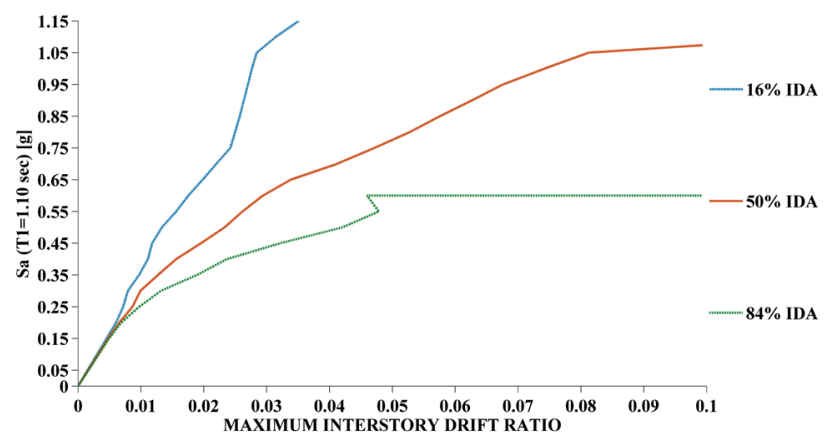

Fig. 9 Not-corroded two-dimentional frame failure in the limit states of $16 \%, 50 \%$ and $84 \%$

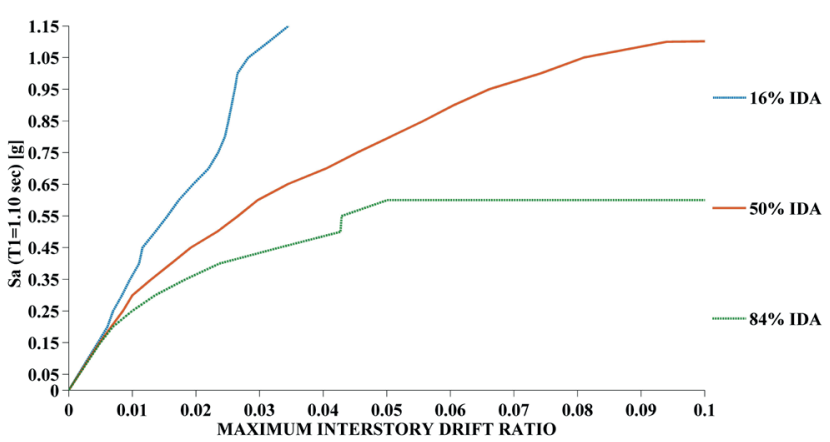

Fig. 10 Corrosion (A) two-dimentional frame failure in the limit states of $16 \%, 50 \%$ and $84 \%$

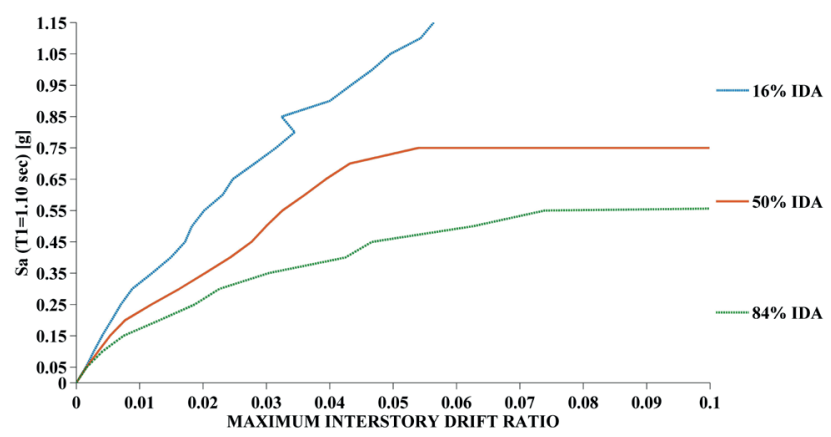

Fig. 11 Corrosion (B) two-dimentional frame failure in the limit states of $16 \%, 50 \%$ and $84 \%$ 


\section{Conclusions}

Corrosion in RC Structures, by changing the mechanical properties of the reinforcement and concrete, such as the cross-section, the yield strength and the modulus of elasticity of the steel as well as the compressive strength of the concrete, reduce the capacity and performance of the structure. In this study, by studying 2D and 3D concrete structures, the moment-curvature curves of the sections as well as the curve of the Pushover analysis and failure curve (IDA) were investigated under different corrosion conditions.

- In the case of low intensity corrosion in the reinforcement, with considering all of the corrosion effects, both uniform and pitting, the ultimate moment and curvature of the section, were reduced and increased, respectively.

- With high intensity corrosion in the reinforcement, with considering all of the corrosion effects, the ultimate moment and curvature of the section, respectively, decreased and increased significantly.

- The structural capacity in the Pushover analysis has been reduced by corrosion, which is further increased by increasing the corrosion process and increasing its

\section{References}

[1] Yalciner, H., Sensoy, S., Eren, O. "Time-dependent seismic performance assessment of a single-degree-of-freedom frame subject to corrosion", Engineering Failure Analysis, 19, pp. 109-122, 2012. https://doi.org/10.1016/j.engfailanal.2011.09.010

[2] Shayanfar, M. A., Barkhordari, M. A., Ghanooni-Bagha, M. "Estimation of corrosion occurrence in RC structure using reliability based PSO optimization", Periodica Polytechnica Civil Engineering, 59(4), pp. 531-542, 2015. https://doi.org/10.3311/PPci.7588

[3] Ghanooni-Bagha, M., Shayanfar, M. A., Reza-Zadeh, O., ZabihiSamani, M. "The effect of materials on the reliability of reinforced concrete beams in normal and intense corrosions", Maintenance and Reliability, 19(3), pp. 393-402, 2017.

https://doi.org/10.17531/ein.2017.3.10

[4] Ghanooni-Bagha, M., Shayanfar, M. A., Farnia, M. H. "Cracking effects on chloride diffusion and corrosion initiation in RC structures via finite element simulation", Scientia Iranica, 2018. https://doi.org/10.24200/SCI.2018.50496.1725

[5] Shayanfar, M. A., Ghalehnovi, M., Safiey, A. "Corrosion effects on tension stiffening behavior of reinforced concrete", Computers and Concrete, 4(5), pp. 403-424, 2007. https://doi.org/10.12989/cac.2007.4.5.403

[6] Berto, L., Simioni, P., Saetta, A. "Numerical modelling of bond behavior in RC structures affected by reinforcement corrosion", Engineering Structures, 30(5), pp. 1375-1385, 2008. https://doi.org/10.1016/j.engstruct.2007.08.003 intensity, as well as considering the corrosion effect on the strength of the steel and concrete at the same time. Specifically, the decrease in the maximum base shear of the two-dimensional structure in the corrosion condition (A) to (E) was $3.07 \%, 50.05 \%, 1.10 \%$, $23.80 \%$ and $24.30 \%$, respectively.

- Application of the coefficient of $\mathrm{k}=0.75$ in the capacity of sections for low intensity corrosion, non-economical and for high intensity corrosion, is unsafe.

- Corrosion, due to the severity and incident scenario, causes changes in the level of performance of the structures.

- In incremental dynamic analysis (IDA) in the two-dimensional structure, with the occurrence of corrosion (A), the maximum interstory drift ratio of the structure has increased slightly, which, of course, does not lead to a change in the seismic performance levels of the structure. However, with the occurrence of corrosion (B), while increasing the amount of structural drift, the seismic performance level changes to $84 \%$ of earthquakes from (IO) to (LS) and under $50 \%$ and $16 \%$ of earthquakes from (LS) to (CP).

[7] Ouglova, A., Berthaud, Y., Foct, F., François, M., Ragueneau, F., Petre-Lazar, I. "The influence of corrosion on bond properties between concrete and reinforcement in concrete structures", Materials and Structures, 41(5), pp. 969-980, 2008. https://doi.org/10.1617/s11527-007-9298-x

[8] Liu, Y., Weyers, R. E. "Modeling the time-to-corrosion cracking in chloride contaminated reinforced concrete structures", ACI Materials Journal, 95(6), pp. 675-680, 1998. [online] Available at: https:// www.concrete.org/publications/internationalconcreteabstractsportal. aspx? $\mathrm{m}=$ details \&ID $=410$ [Accessed:07.05.2019.]

[9] Li, C.-Q., Melchers, R. E., Zheng, J.-J. "Analytical model for corrosion-induced crack width in reinforced concrete structures", ACI Structural Journal, 103(4), pp. 479-487, 2006. [online] Available at: https://www.concrete.org/publications/internationalconcreteabstractsportal/m/details/id/16423 [Accessed:07.05.2019.]

[10] Ghanooni-Bagha, M., Shayanfar, M. A., Shirzadi-Javid, A. A., Ziaadiny, H. "Corrosion-induced reduction in compressive strength of self-compacting concretes containing mineral admixtures", Construction and Building Materials, 113, pp. 221-228, 2016. https://doi.org/10.1016/j.conbuildmat.2016.03.046

[11] Makhmalbaf, M. O., Ghanooni-Bagha, M., Tutunchian, M. A., Zabihi-Samani, M. "Pushover Analysis of Short Structures", World Academy of Science, Engineering and Technology, 5(3), pp. 128-132, 2011. [online] Available at: https://pdfs.semanticscholar.org/7dc0/b7e863fc2331967c4254b5e5d712129ece8e.pdf [Accessed:07.05.2019.] 
[12] Ghanooni-Bagha, M., Ashrafi Gol, M. R., Ranjbar, M. R. "Study of higher mode effect and lateral load patterns in pushover analysis of steel frames with steel shear wall", Advances in Science and Technology Research, 10(29), pp. 13-27, 2016. https://doi.org/10.12913/22998624/61926

[13] Inci, P., Goksu, C., Ilki, A., Kumbasar, N. "Effects of reinforcement corrosion on the performance of RC frame buildings subjected to seismic actions", Journal of Performance of Constructed Facilities, 27(6), pp. 683-696, 2013. https://doi.org/10.1061/(ASCE)CF.1943-5509.0000378

[14] Yalciner, H., Sensoy, S., Eren, O. "Seismic performance assessment of a corroded 50-year-old reinforced concrete building", Journal of Structural Engineering, 141(12), pp. 05015001, 2015. https://doi.org/10.1061/(ASCE)ST.1943-541X.0001263

[15] FEMA, ASCE "Prestandard and commentary for the seismic rehabilitation of buildings", Federal Emergency Management Agency, (Washington D.C.), American Society of Civil Engineers, Reston, Virginia, United States, Rep. FEMA 356, 2000.

[16] Lee, H.-S., Cho, Y.-S. "Evaluation of the mechanical properties of steel reinforcement embedded in concrete specimen as a function of the degree of reinforcement corrosion", International Journal of Fracture, 157(1-2), pp. 81-88, 2009. https://doi.org/10.1007/s10704-009-9334-7

[17] Rodriguez, J., Ortega, L. M., Casal, J. "Load carrying capacity of concrete structures with corroded reinforcement", Construction and Building Materials, 11(4), pp. 239-248, 1997. https://doi.org/10.1016/S0950-0618(97)00043-3

[18] Val, D. V., Stewart, M. G., Melchers, R. E. "Effect of reinforcement corrosion on reliability of highway bridges", Engineering Structures, 20(11), pp. 1010-1019, 1998. https://oi.org/10.1016/S0141-0296(97)00197-1

[19] Shayanfar, M. A., Barkhordari, M. A., Ghanooni-Bagha, M. "Effect of longitudinal rebar corrosion on the compressive strength reduction of concrete in reinforced concrete structure", Advances in Structural Engineering, 19(6), pp. 897-907, 2016. https://doi.org/10.1177/1369433216630367
[20] Scott, B. D., Park, R., Priestley, M. J. N. "Stress-strain behavior of concrete confined by overlapping hoops at low and high strain rates", ACI Journal, 79(1), pp. 13-27, 1982. [online] Available at: https://www.concrete.org/publications/internationalconcreteabstractsportal/m/details/id/10875 [Accessed:08.05.2019.]

[21] Kwak, H.-G., Kim, S,-P. "Nonlinear Analysis of RC Beams Based on Moment-Curvature Relation", Computers and Structures, 80(7-8), pp. 615-628, 2002. https://doi.org/10.1016/S0045-7949(02)00030-5

[22] Haselton, C. B., Liel, A. B., Deierlein, G. G., Dean, B. S., Chou, J. H. "Seismic collapse safety of reinforced concrete buildings. I: Assessment of ductile moment frames", Journal of Structural Engineering, 137(4), pp. 481-491, 2011. https://doi.org/10.1061/(ASCE)ST.1943-541X.0000318

[23] Pacific Earthquake Engineering Research Center, University of California "Open system for earthquake engineering simulation (OpenSEES3.0.3)", [Computer program] Available at: http://opensees.berkeley.edu/ [Accessed:08.05.2019.]

[24] Ibarra, L. F., Medina, R. A., Krawinkler, H. "Hysteretic models that incorporate strength and stiffness deterioration", Earthquake Engineering and Structural Dynamics, 34(12), pp. 1489-1511, 2005. https://doi.org/10.1002/eqe.495

[25] Simioni, P. "Seismic response of reinforced concrete structures affected by reinforcement corrosion", Doctoral Dissertation, University of Florence, 2009. [online] Available at: https://publikationsserver.tu-braunschweig.de/receive/dbbs_mods_00031189 [Accessed:08.05.2019.]

[26] Pacific Earthquake Engineering Research Center, University of California "Pacific earthquake engineering research center, PEER Ground Motion Database", [online] Available at: https://peer.berkeley.edu/ [Accessed:08.05.2019.] 